\title{
PENGARUH KONSERVATISMA AKUNTANSI TERHADAP KEBURAMAN LABA DENGAN KUALITAS AUDIT SEBAGAI VARIABEL PEMODERASI
}

\author{
Oleh: \\ Zuhrohtun \\ Indra Kusumawardhani \\ (UPN "Veteran" Yogyakarta)
}

\begin{abstract}
This study investigates the effect of accounting conservatism on earnings opacity with auditor quality as moderating variable. Sample consists of 240 manufacturing firms that listed on Indonesian Stock Exchange during 2008-2010. This study use regression analysis to test the hypotheses. The finding suggests that accounting conservatism could decrease earnings opacity and auditor quality could decrease earnings opacity as well. But this study couldn't find evidence the moderating effect of auditor quality.
\end{abstract}

Keywords: accounting conservatism, earnings opacity, auditor quality, moderating effect

\section{Latar Belakang}

Keburaman laba adalah suatu ukuran yang mencerminkan sedikitnya informasi dalam angka-angka laba perusahaan mengenai kinerja ekonomi perusahaan yang sesungguhnya, akan tetapi unobservable (Bhattacharya et al., 2003). Indeks keburaman laba di Indonesia ke 32 dari 34 negara (Battacharya et al., 2003). Menurut Battacharya (2003), laba yang dilaporkan dari suatu negara bisa buram, hal ini disebabkan karena adanya interaksi yang kompleks dari paling tidak tiga faktor, yaitu motivasi manajerial, standar akuntansi, dan enforcement terhadap standar akuntansi. Tingginya tingkat keburaman laba menunjukkan keinformatifan laba di Indonesia sangatlah rendah, oleh karena itu sangat penting dilakukan penelitian mengenai faktor-aktor yang mempengaruhi keburaman laba pada perusahaan publik di Indonesia.

Menurut SFAC No. 2 (FASB, 1980) konservatisma adalah reaksi hati-hati (prudent reaction) dalam menghadapi ketidakpastian yang melekat dalam perusahaan untuk mencoba memastikan bahwa ketidakpastian dan risiko bawaan dalam lingkungan bisnis sudah cukup dipertimbangkan. Konservatisma akuntansi dapat dijelaskan dari standar yang sifatnya mandatory maupun dari keleluasaan manajer dalam pemilihan teknik dan metoda akuntansi. Konservatisma merupakan praktik akuntansi dengan mengurangi laba (dan menurunkan nilai aktiva bersih) ketika menghadapi bad news, akan tetapi tidak meningkatkan laba (dan menaikkan nilai aktiva bersih) ketika menghadapi good news (Basu, 1997).

Banyak kritikan mengenai konservatisma akuntansi. Sebagian menganggap konservatisma merupakan praktik akuntansi yang bias dan laba yang dihasilkan kurang berkualitas, tidak relevan, dan tidak bermanfaat. Sedangkan sebagian lainnya menganggap konservatisma akuntansi akan mengurangi periláku oportunistik manajer, menguntungkan kontrak berbagai pihak di dalam perusahaan maupun di luar perusahaan, dan memiliki relevansi nilai. Watts (2003) menyatakan konservatisma akuntansi masih mempunyai manfaat apabila dilihat dari perspektif mekanisme kontrak yang efisien. Peranan auditor yang berkualitas sebagai yang berfungsi monitoring bisa meningkatkan efisiensi mekanisme kontrak dalam perusahaan, selain itu laporan keuangan yang 
konservatif dinilai lebih berkualitas karena lebih mencerminkan antisipasi terhadap ketidakpastian di masa depan, sehingga diduga akan menurunkan tingkat keburaman laba (Battacharya, 2003).

\section{Rumusan Masalah}

Oleh karena sangat menarik untuk menguji secara empiris apakah konservatisma akuntansi dan kualitas audit mempengaruhi tingginya tingkat keburaman pada perusahaan manufaktur di Indonesia dan apakah kualitas audit memoderasi pengaruh konservatisma akuntansi terhadap keburaman laba?

\section{Kerangka Pemikiran}

Bhattacharya et al. (2003), menguji laporan keuangan dari 34 negara tahun 19841998 untuk membuat set datapanel yang mengukur tiga dimensi laba akuntansi yang dilaporkan oleh perusahaan, yaitu keagresifan laba, loss avoidance, dan perataan laba. Kemudian menguji pengaruh ketiga ukuran keburaman laba tersebut terhadap permintaan return oleh pemegang saham dan berapa yang diperdagangkan. Secara keseluruhan, keburaman laba suatu Negara berhubungan dengan peningkatan biaya ekuitas dan menurunkan perdagangan saham di Negara tersebut. Belkaoui (2005) menguji bagaimana kualitas akuntansi yang diukur dengan earnings opacity mempengaruhi stock market wealth effect, yang juga akan berhubungan dengan pertumbuhan ekonomi. Hasil penelitian menunjukkan bahwa stock market wealth effect secara negatif dipengaruhi oleh keburaman laba. Data penelitian juga menunjukkan bahwa komponen eksogen stock market wealth effect yang didefinisikan oleh keburaman laba berhubungan positif dengan pertumbuhan ekonomi. Pengaruh langsung keburaman laba dengan pertumbuhan ekonomi diharapkan negatif, tetapi tidak signifikan.

Belkaoui dan AlNajjar (2006) mengidentifikasi dan menguji faktor-faktor yang mempengaruhi keburaman laba dalam konteks internasional. Keburaman laba secara internasional berhubungan negative dengan level kebebasan ekonomi dan kualitas hidup hubungan positif dengan peraturan hukum, pertumbuhan ekonomi dan tingkat korupsi. Akan tetapi tingkat disclosure, jumlah auditor per 100.000 penduduk dan pengadopsian srandar akuntansi internasional (sebagai elemen accounting order) tidak berhubungan secara signifikan dengan keburaman laba. Meningkatnya kualitas informasi keuangan dapat mengurangi asimetri informasi, sehingga dapat menurunkan cost of capital (Amihud dan Mendelson, 1986; Diamond dan Verrecchia, 1991). Perusahaan dapat mengurangi asimetri informasi antar perusahaan dan antar partisipan pasar, antar informed dan uninformed investor dengan menyediakan informasi yang membantu mereka dalam proses pengambilan keputusan. Hasil penelitian empiris menunjukkan bahwa tingkat pengungkapan berhubungan dengan cost of equity capital (Botosan, 1997; Botosan dan Plumlee, 2002).

Ratti et al. (2008) menguji pengaruh konsentrasi bank terhadap kendala finansial dari keputusan investasi perusahaan di 14 negara Eropa antara tahun 1992 dan 2005. Penelitian tersebut menggunakan data panel perusahaan non keuangan untuk menganalisis kendala finansial dengan persamaan Euler yang diturunkan dari model investasi dinamik. Hasil penelitian menunjukkan perusahaan sektor perbankan yang terkonsentrasi tinggi kurang terkendala secara finansial. Hasid penelitian tersebut tetap robust setelah dikontrol dengan keburaman perusahaan, ukuran perusahaan, dan siklus bisnis. Secara keseluruhan hasil penelitian konsisten dengan hipotesis berbasis informasi, yaitu bahwa semakin tinggi kekuatan pasar maka bank terdorong untuk memproduksi informasi pada peminjam potensial. Temuan tersebut robust setelah dikontrol dengan faktor-faktor institusional spesifik tiap negara. 
Cristensen et al. (2010) menyatakan bahwa meningkatnya pengungkapan publik akan mengurangi kos ekuitas perusahaan. Fokus penelitian tersebut adalah pengaruh informasi terhadap kos ekuitas setelah pengumuman informasi (ex post cost of capital). Hasil penelitian menunjukkan bahwa penurunan ex post cost of capital diikuti oleh peningkatan kos ekuitas yang sama setelah pengumuman informasi. Sehubungan dengan informasi yang disediakan secara publik maupun privat mempengaruhi waktu resolusi ketidakpastian dan ketika informasi tercermin dalam harga ekuilibrium, akan tetapi tidak ada dampak pada harga awal. Daouk et al. (2005) menguji hubungan antara capital market governance (CMG) dan beberapa ukuran kinerja pasar. Ukuran indeks CMG mencakup tiga dimensi hukum-hukum sekuritas: tingkat keburaman laba, pelaksanaan insider law, dan pengaruh penghilangan pembatasan short selling. Penelitian tersebut membuktikan bahwa perbaikan $\mathrm{CMG}$ indeks berhubugan dengan menurunnya cost of equity capital, meningkatnya likuiditas pasar, meningkatnya harga efisiensi harga pasar.

Konservatisma merupakan konvensi laporan keuangan yang penting dalam akuntansi, sehingga disebut sebagai prinsip akuntansi yang dominan. Konvensi seperti konservatisma menjadi pertimbangan dalam akuntansi dan laporan keuangan karena aktivitas perusahaan dilingkupi oleh ketidakpastian. Menurut Givoly dan Hayn (2000), konservatisma akuntansi adalah suatu kriteria pemilihan prinsip-prinsip akuntansi yang mengarah pada minimalisasi laba yang dilaporkan, dengan memperlambat pengakuan pendapatan, mempercepat pengakuan biaya, menilai aktiva lebih rendah dan menilai utang lebih tinggi. Konservatisma adalah memilih prinsip akuntansi yang mengarah pada minimalisasi laba kumulatif yang dilaporkan, yaitu mengakui pendapatan lebih lambat dan mengakui biaya lebih cepat, menilai aktiva dengan nilai yang lebih rendah dan menilai kewajiban dengan nilai yang lebih tinggi (Dewi, 2004).

Bhattacharya et al. (2003) berargumen bahwa konservatisme yang menunda mengakui laba dan lebih cepat mengakui rugi akan mengurangi asimetri informasi, sehingga tingkat keburaman laba menurun. Selain itu dorongan manajerial untuk melaporkan laba lebih tinggi akan menambah "noise" dalam laba yang dilaporkan sehingga meningkatkan keburaman laba. Oleh karena itu diduga konservatisma akuntansi akan berpengaruh negative terhadap keburaman laba, sehingga diajukan hipotesis 1 sebagai berikut:

\section{H1: Semakin tinggi tingkat konservatisma akuntansi akan menurunkan tingkat keburaman laba}

Balsam et al. (2003) menunjukkan bahwa kualitas auditor merupakan salah satu faktor yang dapat membatasi tingkat diskresi yang dilakukan klien. Reynold dan Francis (2001) berargumen bahwa auditor yang berkualitas tinggi (diproksi dengan brand name yaitu auditor Big 6 dalam penelitian mereka) mampu mendeteksi manajemen laba dan membatasi perilaku opportunis manajer karena auditor tersebut mempunyai pengetahuan yang superior dibandingkan auditor yang kurang berkualitas. Francis dan Wang (2006) juga berargumen bahwa auditor Big 4 akan menekankan tingkat kualitas laba klien yang tinggi untuk menjaga reputasi nama mereka dari tuntutan litigasi. Hasil-hasil penelitian terdahulu telah menunjukkan bahwa perusahaan-perusahaan yang menjadi klien auditor yang mempunyai brand name yang tinggi (misal Big 4) mempunyai akrual diskresionari yang lebih rendah (Francis dan Wang, 2006). Hal ini konsisten dengan dugaan bahwa auditor Big 4 membatasi praktek manajemen laba yang agresif sehingga menghasilkan laba yang berkualitas.

Selain dengan brand name auditor, kualitas audit juga dapat diukur dengan spesialiasi industri auditor (misal Balsam et al. 2003). Dengan menggunakan berbagai proksi untuk mengukur spesialisasi industri auditor, Balsam et al. (2003) menunjukkan bahwa perusahaan yang diaudit oleh auditor spesialis industri mempunyai akrual 
diskresionari yang lebih rendah dibandingkan dengan perusahaan-perusahaan yang diaudit oleh auditor yang bukan spesialis dalam industri tersebut. Temuan-temuan di atas menunjukkan bahwa auditor yang berkualitas (baik diukur dengan brand name auditor maupun spesialiasi industri) yang tinggi mampu membatasi tindakan oportunis manajemen laba berbasis akrual yang dilakukan klien perusahaan. KAP yang lebih besar akan melakukan audit lebih baik karena mereka mempunyai sumber daya dan reputasi yang baik. Krishnan (2002) menyatakan bahwa investor menganggap KAP besar memiliki kualitas audit yang lebih tinggi karena memiliki karakteristik-karakteristik yang berhubungan dengan kualitas audit yang lebih bisa diamati, seperti: specialized training dan peer review. Belkoui dan AlNajjar (2006) menyatakan bahwa keburaman laba pada tiap negara akan menurun seiring dengan meningkatnya tingkat disclosure, jumlah auditor, dan pengadopsian standar akuntansi internasional. Oleh karena itu diduga kualitas audit akan berpengaruh negative terhadap keburaman laba, sehingga diajukan hipotesis kedua sebagai berikut: H2: Semakin bagus kualitas audit perusahaan maka semakin rendah tingkat
keburaman laba.

Menurut Balsam et al. (2003) kualitas auditor merupakan salah satu faktor yang dapat membatasi tingkat diskresi yang dilakukan klien. Pada perusahaan yang tingkat konsevatisma akuntansinya tinggi, akan membatasi tingkat diskresi manajemen, sehingga apabila diaudit oleh auditor yang berkualitas maka akan mempersempit tingkat diskresi manajemen. Oleh karena itu diduga kualitas audit memoderasi pengaruh konservatisma akuntansi terhadap keburaman laba, maka hipotesis ketiga dalam penelitian ini adalah:

H3: Semakin tinggi tingkat konservatisma akuntansi pada perusahaan yang diaudit oleh KAP Big Four, maka tingkat keburaman labanya akan semakin rendah.

\section{Metode Penelitian}

Penelitian ini menggunakan data sekunder yang diperoleh dari data base website Bursa Efek Indonesia yaitu www.idx.co.id. Populasi penelitian ini adalah seluruh perusahaan manufaktur yang terdaftar di Bursa Efek Indonesia pada tahun 2008-2010. Metoda pemilihan sampel adalah dengan purposive sampling, dengan kriteria sebagai berikut: (1) Laporan keuangan tahunan perusahaan tersebut tersedia secara lengkap; (2) Saham perusahaan aktif diperdagangkan di BEI selama perioda penelitian.

\section{Konservatisma akuntansi} 2002):

Rumus untuk menghitung akrual adalah sebagai berikut (Givoly dan Hayn,

Keterangan:

$$
\mathrm{CI}_{\mathrm{it}}=\mathrm{NI}_{\mathrm{it}}-\mathrm{CF}_{\mathrm{it}}
$$

$$
\begin{array}{ll}
\mathrm{CI}_{\text {it }} & \text { : tingkat konservatisma } \\
\mathrm{NI}_{\text {it }} & \text { : net income sebelum extraordinary items } \\
\mathrm{CF}_{\text {it }} & : \text { Cash flow dari kegiatan operasional }
\end{array}
$$

\section{Kualitas audit}

Kualitas audit diukur dengan variabel dummy, 1 bila perusahaan diaudit KAP Big 4 dan 0 jika tidak.

\section{Ukuran Perusahaan}

Ukuran perusahaan diukur dengan Ln total aset.

Size $_{\mathrm{t}}=$ Ln Total Asset $\mathrm{t}_{\mathrm{t}}$ 
Variabel dependen dalam penelitian ini adalah Keburaman Laba, yang diukur dengan akrual diskresioner selama tiga tahun (Hutton et al., 2009), dengan langkahlangkah sebagai berikut:

$$
\begin{aligned}
& \frac{T A C C_{j t}}{T A_{j t-1}}=\alpha \frac{1}{T A_{j t-1}}+\beta_{1} \frac{\Delta S A L E_{j t}}{T A_{j t-1}}+\beta_{2} \frac{P P E_{j t}}{T A_{j t-1}}+\varepsilon_{j t} \text {. }
\end{aligned}
$$

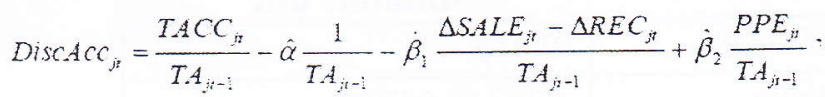

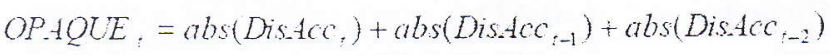

Keterangan:

TACCjt : Total akrual perusahaan $\mathrm{j}$ pada perioda $\mathrm{t}$ (dihitung dengan laba bersih dikurangi arus kas operasi)

DiscAccjt : Akrual diskresioner perusahaan $\mathrm{j}$ pada perioda $\mathrm{t}$

$\triangle$ SALEjt $\quad$ : Perubahan penjualan perusahaan $\mathrm{j}$ pada perioda $t$

$\triangle$ RECjt : Perubahan piutang perusahaan $\mathrm{j}$ pada perioda $t$

PPEjt : Nilai bersih asset tetap perusahaan $\mathrm{j}$ pada perioda $\mathrm{t}$

TAjt-1 : Total asset perusahaan $\mathrm{j}$ pada perioda $\mathrm{t}-1$

Variabel pemoderasi dalam penelitian ini adalah kualitas audit, yang diukur dengan variabel dummy yaitu: 1 jika perusahaan diaudit oleh KAP Big Four, dan 0 jika bukan KAP Big Four.

Hipotesis dalam penelitian ini diuji dengan ini menggunakan analisis regresi berganda, dengan efek interaksi dengan persamaan sebagai berikut:

$\mathrm{KL} \mathrm{i}_{\mathrm{t}}=$

$$
\alpha+\beta_{1} \text { Konsi }_{\mathrm{t}}+\beta_{2} \text { AuditQi }_{\mathrm{t}}+\beta_{3} \text { Konsi }_{\mathrm{t}}{ }^{*} \text { AuditQi }_{\mathrm{t}}+\beta_{4} \text { Sizei }_{\mathrm{t}}+\beta_{5} \text { Levi }_{\mathrm{t}}+\mathrm{e}
$$

Keterangan:

$\mathrm{KL} \mathrm{i}_{\mathrm{t}}$

Konsi $_{t}$

AuditQi $i_{t}$

Konsi $_{t} *$ AuditQi $_{i}$

Sizei

Levi $i_{t}$
Keburaman laba perusahaan i pada perioda $t$

: Tingkat konservatisma akuntansi perusahaan i pada perioda $\mathrm{t}$

: Variabel Dummy Kualitas audit, 1 bila perusahaan diaudit KAP Big 4 dan 0 jika tidak

: Efek Interaksi antara Konservatisma Akuntansi dan Variabel dummy Kualitas audit

: Ukuran perusahaan i pada perioda $t$

: Leverage perusahaan i pada perioda $t$

Sebelum dilakukan pengujian menggunakan regresi berganda, terlebih dahulu dilakukan uji asumsi klasik. Uji asumsi klasik yang harus dipenuhi meliputi tidak adanya autokorelasi, heteroskedastisitas, multikolinieritas dan asumsi normalitas untuk pengujian regresi.

Secara keseluruhan sampel dalam penelitian ini adalah 240 perusahaan yang memenuhi kriteria pemilihan sampel. Observasi selama tiga tahun, jadi total observasi adalah 720 perusahaan.

Sebelum dilakukan pengujian hipotesis terlebih dahulu dilakukan pengujian asumsi klasik, dan model penelitian ini memenuhi asumsi normalitas, autokorelasi, heteroskedastisitas, dan multikolinearitas. 
Hipotesis 1, 2, dan 3 dalam penelitian ini diuji dengan analisis regresi berganda dengan hasil disajikan pada Tabel .1 berikut ini:

Tabel 1. Hasil Pengujian Hipotesis

\begin{tabular}{|l|l|l|}
\hline \multicolumn{1}{c|}{$\begin{array}{c}\text { Independent } \\
\text { Variable }\end{array}$} & & \multicolumn{1}{c|}{\begin{tabular}{c} 
Dependent Variable \\
\cline { 3 - 3 }
\end{tabular}} \\
\hline Conservatism & Coefficient & -0.036 \\
\hline AuditQ & t-statistic & $1.267(0.047)^{*}$ \\
\hline & Coefficient & -0.477 \\
\hline Size & t-statistic & $0.871(0.048)^{*}$ \\
\hline & Coefficient & 0.352 \\
\hline Conservatism*AuditQ & t-statistic & $0.469(0.042)^{*}$ \\
\hline & Coefficient & -0.179 \\
\hline Leverage & t-statistic & $1.272(0.063)$ \\
\hline & Coefficient & 0.083 \\
\hline Adj $\mathrm{R}^{2}$ & t-statistic & $0.224(0.063)$ \\
\hline
\end{tabular}

Berdasarkan Tabel 1 di atas, variabel konservatisma akuntansi memiliki koefisien negatif, dengan nilai signifikansi sebesar 0.047 . oleh karena nilai signifikansinya kurang dari 0.05 maka hipotesis 1 dalam penelitian ini di dukung. Artinya semakin tinggi tingkat konservatisma akuntansi akan menurunkan tingkat keburaman laba. Hal ini mengindikasikan bahwa konservatisma akuntansi akan membatasi diskresi manajemen untuk mengelola laba untuk tujuan oportunistik. Variabel kualitas audit juga memiliki koefisien negatif dengan tingkat signifikansi 0.048 . Oleh karena nilai signifikansinya kurang dari 0,05 maka hipotesis 2 dalam penelitian ini juga didukung. Artinya semakin tinggi kualitas audit akan menurunkan tingkat keburaman laba. Hal ini mengindikasikan bahwa keberadaan auditor yang berkualitas dapat membatasi diskresi manajemen, karena auditor yang berkualitas mempunyai kemampuan yang superior untuk mendeteksi laba yang buram.

Berdasarkan Tabel 1 di atas, interaksi antara konservatisma tidak signifikan, karena nilai signifikansinya lebih besar dari 0.05 , yaitu sebesar 0.063 . Hal ini berarti model dalan penelitian ini gagal membuktikan efek moderasi dari kualitas auditor pada pengaruh konservatisma terhadap keburaman laba. sehingga hipotesis ketiga dalam penelitian ini tidak didukung.

Variabel ukuran perusahaan memiliki koefisien positif dan nilai signifikansinya kurang dari 0.05 yaitu 0.042 , jadi semakin tinggi ukuran perusahaan akan meningkatkan keburaman laba. Hal ini dikarenakan perusahaan besar cenderung akan menghindari visibilitas publik sehingga cenderung membuat labanya buram. Sedangkan variabel Leverage tidak berpengaruh signifikan karena nilai signifikasinya lebih besar dari 0.05 , hal ini menunjukkan bahwa tinggi rendahnya rasio utang terhadap aset perusahaan tidak berpengaruh terhadap keburaman laba. kebijakan utang dalam perusahaan tidak memotivasi manajer untuk membuat laba menjadi buram, dikarenakan utang adalah klaim. Nilai Adj $R^{2}$ sebesar 0.014 mengindikasikan bahwa variasi keburaman laba bisa dijelaskan oleh model sebesar 1,4 persen. Sedangkan sisanya dijelaskan oleh variabel lain yang tidak dijelaskan dalam model. 


\section{Simpulan}

Penelitian ini menguji pengaruh konservatisma akuntansi terhadap keburaman laba dengan kualitas audit sebagai variabel pemoderasi. Hasil penelitian menunjukkan bahwa konservatisma akuntansi mampu menurunkan keburaman laba. Hal ini dikarenakan konservatisme yang menunda mengakui laba dan lebih cepat mengakui rugi akan mengurangi asimetri informasi, sehingga tingkat keburaman laba menurun, sehingga hal ini konsisten dengan argumen Battacharya et al. (2003).

Kualitas audit terbukti mampu menurunkan tingkat keburaman laba, karena auditor yang berkualitas mampu mendeteksi manajemen laba dan membatasi perilaku opportunis manajer karena auditor tersebut mempunyai pengetahuan yang superior dibandingkan auditor yang kurang berkualitas. Selain itu auditor yang berkualitas akan menekankan tingkat kualitas laba klien yang tinggi yaitu rendahnya tingkat keburaman laba untuk menjaga reputasi nama mereka dari tuntutan litigasi. Keberadaan auditor yang berkualitas mampu menambah efektifitas tata kelola perusahaan dalam kebijakan transparansi pelaporan keuangan perusahaan. Hasil penelitian ini konsisten Francis dan Wang (2006) dan Belkoui dan AlNajjar (2006).

Penelitian ini memiliki beberapa keterbatasan; 1) hanya menggunakan satu proksi untuk keburaman laba yaitu nilai absolut akrual diskresioner selama tiga tahun, untuk penelitian selanjutnya sebaiknya menggunakan indeks keburaman laba dengan menggunakan banyak proksi karena keburaman laba adalah variabel yang tidak terobservasi; 2) proksi kualitas audit dalam penelitian ini hanya menggunakan brand name, penelitian selanjutnya sebaiknya menggunakan kualitas kertas kerja audit sebagai ukuran kualitas auditor.

\section{Daftar Pustaka}

Ahmed, Anwer S., Bruce Billings, Marry S. Harris, dan Richard M. Morton. 2000. "Accounting Conservatism and Cost of Debt: An Empirical Test of Efficient Contracting." SSRN Working Paper.

Amihud, Y. dan H. Mendelson. 1986. Asset Pricing and the Bid-Ask Spread. Journal of Financial Economics 17: 223-249.

Anderson, R.C. dan Reeb, D.M. 2003. Founding-Family Ownership and Firm Performance: Evidence from the S\&P 500. The Journal of Finance, Vol 58 No 3, pp. 1301-1328

Anderson, Ronald. Augustine Durub dan David Reeb. 2006. Family Ownership and Corporate Opacity in the U.S. Working Paper

Arping, Sefen, dan Zacharias Sautner. 2010. Did the Sarbanes-Oxley Act of 2002 Make Firms Less Opaque? Evidence from Analyst Earnings Forecasts. SSRN Working Paper

Ball, R., 2009. Market and Political/Regulatory Perspectives on the Recent Accounting Scandals. Journal of Accounting Research 47, 277-323.

Basu, Sudipta. 1997. "The Conservatism Principle and the Asymetric Timeliness of Earnings." Journal of Accounting and Econimics. Vol. 14. No. 1: 3-37.

Belkaoui, Ahmed Riahi. 2005. Earnings Opacity, Stock Market Wealth Effect, and Economic Growth. Review of Accounting \& finance. Vol. 4 No.1. hal. $72-91$

Belkaoui, Ahmed Riahi, dan Fouad k. AlNajjar. 2006. Earnings Opacity Internatinally and Elements of Social, Economic and Accounting Order. Review of Accounting and Finance. Vol. 5 No.3. hal.189-203 
Bhattacharya, Utpal., Hazem Daouk, dan Michael Welker. 2003. The World Price of Earnings Opacity. The Accounting Review Vol. 78. No. 3. P. 641-678.

Claessens, S., S. Djankov, dan L.H.P. Lang. 2000. The Separation of Ownership and Control in East Asian Corporations. Journal of Financial Economics, Vol. 58: 81-112.

Diamond, D., Verrecchia, R., 1991. Disclosure, liquidity, and the cost of capital, Journal of Finance 46, 1325- 1360.

Eckel, Norm. 1981. The Income Smoothing Hypothesis Revisited. Abacus. Vol. 17 No.1 : 28-40.

Faccio, M. and Lang, L.H.P. 2002. The ultimate ownership of Western European corporations. Journal of Financial Economics 65(3): 365-395.

Favero, C.A., Giglio, S.W., Honorati, M., and Panunzi, F. 2006. "The Performance of Italian Family Firms", ECGI Working Paper No. 127/2006,

Finkelstein, S., 1992, Power in Top Management teams: Dimensions, Measurement, and Validation, Academy of Management Journal 35 (3), 505-538.

Givoly, D. dan C. Hayn. 2000. "The Changing Time-series Properties of Earnings, Cashflows and Accruals: Has Financial Reporting Become More Conservative?" Journal of Accounting and Economics, 29: 287-320

Hutton, Ammy P, Alan J. Marcus, and Hassan Tehranian. 2009. Opaque Financial Reports, R, and Crash Risk. Journal of Financial Economics. 94, 67-86.

Kim, Jeong-Bon, dan Liandong Zhang. 2010. Financial Reporting Opacity and Implied Volatility Smirks: Firm-Level Evidence. SSRN Working Paper.

Kothari, S.P., Shu, S., Wysocki, P.D., 2009. Do Managers Withhold Bad News? Journal of Accounting Research 47, 241-276.

Krishnan, G. 2002. Audit Quality and The Pricing of Discretionary Accruals. Working Paper.

Lafond, Ryan., Watts, R.L. 2006. The Information Role of Conservative Financial Statements. http://papers.ssrn.com

La Porta, R., Lopez-de-Silanes, F. and Shleifer, A. (1999). Corporate Ownership Around the World. Journal of Finance, 54, 471-517.

Leuz, C., Verecchia, R., 2000. The economic consequences of increased disclosure, Journal of Accounting Research, 38, 91-124.

Linsley, Philip M., dan Philip J. Shrives . 2005. Examining Risk Reporting in UK Public Companies. The Journal of Risk Finance. Vol. 6, No. 4. Hal. 292-305

Penman, S. H., dan X. J. Zhang. 2002. Accounting Conservatism: The Quality of Earnings and Stock Returns. The Accounting Review 77 (2): 237-264.

Sraer, D. and Thesmar, D. 2006. Performance and Behavior of Family Firms: Evidence from theFrench Stock Market, ECGI Working Paper No. 130/2006.

Wagner, Wolf. 2009. Financial Development and the Opacity of Banks. SSRN Working Paper

Watts, Rose L. 2003. "Conservatism in Accounting Part I: Explanations and Implications." Accounting Horizons. Vol. 17. No. 3. (September): 207-221.

Watts R. and J.L. Zimmerman. 1986. Positive Accounting Theory. New York: PrenticeHall. 